\title{
PENERAPAN METODE PENEMUAN TERBIMBING DALAM MENINGKATKAN KEMAMPUAN BERPIKIR LOGIS ANAK USIA 3-4 TAHUN DI PPT TERATAI KENJERAN SURABAYA
}

\author{
Sri Karmiati \\ PPT Teratai, Surabaya \\ e-mail : srikarmiatisby76@gmail.com
}

\begin{abstract}
Abstrak
Penelitian ini bertujuan untuk mengetahui peningkatan kemampuan berpikir logis anak usia 3-4 tahun di PPT Teratai Kenjeran Surabaya melalui penerapan Metode Penemuan Terbimbing dalam meningkatkan kemampuan berpikir logis anak usia 3-4 tahun di PPT Teratai Kenjeran Surabaya. Jenis penelitian ini adalah penelitian tindakan kelas dengan subyek sebanyak 15 orang anak yang berusia 3-4 tahun dan obyeknya adalah penerapan metode penemuan terbimbing dalam meningkatkan kemampuan berpikir logis. Pengumpulan data menggunakan metode observasi, wawancara dan dokumentasi. Data yang dikumpulkan dianalisa dan direfleksi secara diskriptif kuantitatif. Hasil penelitian menunjukan bahwa pada tindakan siklus I sebanyak 4 anak (25\%) kemampuan berpikir logis anak berkembang sangat baik (BSB) hal ini menunjukan bahwa tingkat kemampuan berpikir logis anak tergolong masih rendah. Tindakan pada siklus II ada peningkatan kemampuan berpikir logis sebesar 13 anak (80\%) dengan kreteria berkembang sangat baik (BSB). Maka dapat di simpulkan bahwa penerapan Metode Penemuan Terbimbing dalam meningkatkan kemampuan berpikir logis anak usia 3-4 tahun di PPT Teratai Kenjeran Surabaya dapat diterapkan dengan hasil yang baik.
\end{abstract}

Kata-kata kunci : Metode Penemuan Terbimbing, berpikir logis

\begin{abstract}
This study aims to determine the increase in the ability to think logically children aged 3-4 years in PPT Kenjeran Surabaya through the application of the Guided Discovery Method. This type of research is classroom action research with subjects of 15 children aged 3-4 years and the object is the application of guided discovery methods in improving logical thinking skills. Data collection using the method of observation, interviews and documentation. The data collected is analyzed and reflected descriptively quantitatively. The results showed that in the first cycle of action as many as 4 children (25\%) the ability of logical thinking children develop very well (BSB) this shows that the level of children's logical thinking ability is still low. Actions in cycle II have an increase in the ability to think logically by 13 children (80\%) with very well developed criteria (BSB). So it can be concluded that the application of the Guided Discovery Method in improving the logical thinking ability of children aged 3-4 years in PPT Lotus Surabaya can be applied with good results.
\end{abstract}

Key words: Guided Discovery Method, logical thinking 


\section{PENDAHULUAN}

Pendidikan anak usia dini merupakan upaya sadar untuk meningkatkan pertumbuhan dan perkembangan anak usia 0-6 tahun. Pada UU nomor 20 tahun 2003 pasal 1 butir 14 tentang pendidikan nasional disebutkan bahwa : Pendidikan anak usia dini merupakan suatu upaya pembinaan yang ditujukan kepada anak sejak lahir sampai dengan usia enam tahun yang dilakukan melalui pemberian rangsangan pendidikan untuk membantu pertumbuhan dan perkembangan jasmani dan rohani agar anak memiliki kesiapan dalam memasuki pendidikan lebih lanjut

Novan dan Barnawi (2012:32) mengemukakan bahwa,"usia dini merupakan usia emas yang sangat menentukan dalam pembentukan karakter dan kepribadian anak, yang mengalami pertumbuhan dan perkembangan yang pesat".Penting sekali bagi orang tua atau guru memberikan rangsangan seluruh aspek perkembangan anak agar bisa berkembang secara optimal . Melalui Sekolah sebagai wadah pendidikan yang layak bagi anak untuk mengembangkan semua aspek perkembangannya. Ada enam aspek perkembangan yang wajib di stimulus yaitu perkembangan aspek moral dan agama, perkembangan aspek kognitif, perkembangan aspek motorik, perkembangan aspek bahasa, perkembangan aspek sosialemosional, perkembangan seni.

Perkembangan kognitif merupakan salah satu aspek perkembangan yang harus distimulus pada anak usia dini. Perkembangan kognitif dapat juga diartikan sebagai perkembangan intelektual yang perkembangannya dipengaruhi oleh kematangan otak yang mampu bekerja secara baik dalam funsinya. Perkembangan kognitif menurut Jean Piaget (Supriadi 2013: 99) kognisi digambarkan sebagai suatu proses evolusioner dan perkembangan yang membentang dari reaksi pertama sensori motor melalui formasi (pembentukan) pemikiran reflektif. Tahapan perkembangan kognitif menurut Jean Piaget adalah:

(a)Tahap pertama perkembangan kognitif menurut Piaget adalah tahap sensorimotor (usia 0-2 tahun) melibatkan koordinasi rasa impresi dan gerakan, (b)Tahap yang kedua yaitu tahap praoperasional (usia 2-7 tahun) yang melibatkan pengelompokan refleksi suatu obyek melalui langkahlangkah memapankan pemikiran secara simbolik, pencapaian operasional kongkrit,(c)Tahap yang ketiga adalah tahap operasi kongkret ( usia 7-11 tahun) dimana stuktrur logika dan pengalaman fisikal berkembang,(b)Tahap yang ke empat adalah tahap operasional formal (usia 11-15 tahun) pada tahap ini pemikiran konseptual melibatkan kecerdasan reflektif dan berfikir formal, termasuk alasan kausal.

Menurut Enah Suminah dalam buku kerangka dasar dan struktur kurikulum 2013 (2015: 31) Direktorat pembinaan Pendidikan Anak Usia Dini "berfikir logis adalah mengenal berbagai perbedaan, klasifikasi, pola, berinisiatif, berencana, dan mengenal sebab akibat yang terjabar dalam kompetensi dasar mengenal benda-benda disekitarnya (nama, warna, bentuk, 
ukuran, pola, sifat, suara, tekstur, fungsi, dan ciri-ciri lainnya) dan menyampaikan tentang apa dan bagaimana benda-benda disekitar yang dikenalnya (nama, warna, bentuk, ukuran, pola, sifat, suara, tekstur, fungsi dan ciri-ciri lainnya) melalui berbagai hasil karya."

Berbagai Metode pembelajaran dapat digunakan dalam pembelajaran anak usia dini. Fadhillah (2014:161)"Metode pembelajaran adalah suatu cara upaya atau system yang digunakan dalam pembelajaran yang bertujuan agar anak didik dapat mengetahui, memahami, mempergunakan, dan menguasai bahan pembelajaran tertentu" . Sund (dalam Abimayu 2010) mengemukakan bahwa Discovery adalah "proses mental dimana siswa mampu memaksimalkan sesuatu konsep atau prinsip". Yang dimaksudkan dengan proses mental tersebut antara lain mengamati, mencerna, mengerti, menggolong-golongkan, membuat dugaan, menjelaskan, mengukur, membuat kesimpulan, dan sebagainya. Dalam penelitian ini peneliti menggunakan Metode Penemuan Terbimbing. Penemuan terbimbing (guided discovery) dalam pembelajarannya guru masih memberi petunjuk pada siswa untuk menbantu siswa menghindari jalan buntu. Guru memberi pertanyaan dan menceritakan permasalahan yang ada, menyediakan materi-materi yang menarik dan sesuai dengan tingkat perkembangan peserta didik. Dalam (Bektiarso,2015:63)Supriyati \& Anita (2007)mengemukakan bahwa salah satu bentuk pembelajaran penemuan (discovery learning) adalah pembelajaran penemuan terbimbing (guided discovery learning). Eggen(2012:177) mengatakan bahwa "penemuan terbimbing (guided discovery) adalah satu pendekatan mengajar dimana guru memberi siswa contoh-contoh topik specifik dan memandu siswa untuk memahami topik tersebut". Pembelajaran penemuan terbimbing (guided discovery learning) lebih banyak digunakan dikarenakan dengan petunjuk guru peserta didik bekerja lebih terarah dalam upaya memecahkan masalah atau tujuan yang akan dicapai. Namun demikian guru hanya sebagai fasilitator .

Berdasarkan observasi yang dilakukan di PPT Teratai Kenjeran Surabaya menunjukan bahwa ada peserta didik yang masih memerlukan motivasi dan pendampingan dari guru, masih ada peserta didik dengan kreteria masih berkembang dalam aspek perkembangan kognitifnya . Hasil observasi terhadap guru kelas . Bahwa masih ada peserta didik yang masih berkembang dalam kemampuan kognitif berpikir logis dalam mengetahui ukuran benda besar dan kecil, mengetahui ukuran panjang dan pendek benda, mengelompokan benda berdasarkan jenis atau warnanya, mengetahui bagian benda yang hilang. Dengan permasalahan tersebut Peneliti menerapkan Metode Penemuan Terbimbing dalam meningkatkan berpikir logis anak usia 3-4 tahun di PPT Teratai Kenjeran Surabaya. Metode Penemuan Terbimbing memberikan kesempatan kepada anak untuk mengetahui konsep berpikir logis dengan pengetahuannya sendiri . Peserta didik lebih antusias terlibat dalam 
kegiatan pembelajaran sehingga memudahkan guru dalam memberikan pembelajaran. Guru hanya sebagai fasilisator dan pembimbing. Dengan menerapkan metode Penemuan Terbimbing dengan kegiatan membedakan ukuran besar dan kecil, pnjang dan pendek, anak-anak mengelompokkan benda sesuai dengan ukuran dan jenisnya , menggukur panjang sedotan yang satu dengan sedotan yang lebih pendek, dengan mengamati, membedakan, penalaran anak akan menemukan konsep berpikir logis .

\section{METODE PENELITIAN}

Penelitian ini dilakukan di PPT Teratai Kenjeran Surabaya dengan subyek sejumlah 15 orang anak , 10 orang anak perempuan dan 5 orang anak laki-laki. Kegiatan penelitian ini dilakukan langsung oleh peneliti dan guru berpartisipasi membantu dalam proses pembelajaran. Objek penelitian ini adalah kemampuan berpikir logis anak usia 3-4 tahun di PPT Teratai Kenjeran Surabaya. Dengan di terapkannya Metode Penemuan Terbimbing, hipotesa dari peneliti ini kemampuan berpikir logis anak dalam mengetahui ukuran besar dan kecil benda, panjang dan pendek benda, mengelompokan benda berdasarkan jenis atau warnanya dapat meningkat. Jenis penelitian yang digunakan adalah penelitian tindakan kelas. Penelitian tindakan kelas (PTK) juga didefinisikan oleh Arikunto.dkk,2007:3 yaitu Penelitian Tindakan Kelas (PTK) merupakan suatu pencermatan terhadap kegiatan belajar berupa sebuah tindakan yang sengaja di munculkan dan terjadi dalam sebuah kelas secara bersama. Prosedur dan rancangan penelitian ini menggunakan model penelitian yang dikemukakan oleh Kemmis dan Mc Tanggart. yaitu model penelitian dengan dua siklus, Siklus I dilaksanakan pada tanggal 20-22 Mei 2019 dan siklus II dilaksanakan pada tanggal 27-29 Mei 2019 . Setiap silkus dilaksanakan dengan tiga kali pertemuan dengan waktu 90 menit tiap pertemuan dengan Prosedur pelaksanaan dalam penelitian tindakan kelas ini ada 4 tahapan pelaksanaannya sebagai berikut:
a) Perencanaan (planning)
b) Pelaksanaan (acting)
c) Pengamatan (observing)
d) Refleksi (reflecting) (Arikunto, 2007: 16).

\section{HASIL DAN PEMBAHASAN \\ Hasil}

Pada tahap perencanaan ,peneliti merencanakan kegiatan dengan menyusun RPPH , instrument evaluasi atau observasi., menyiapkan kelas, media dan alat yang akan digunakan.Tahap pelaksanaan guru melakukan tindakan penelitian dengan dua siklus. Siklus I dilaksanakan 3 kali pertemuan dengan waktu 90 menit tiap pertemuan, pertemuan pertama guru mengajak anak-anak untuk membedakan bentuk dan 
ukuran biji-bijian, ada biji kacang hijau, biji kedelai dan biji kacang merah. Anak-anak mengamati mengelompokkan biji-bijian sesuai jenis dan ukurannya. Pertemuan kedua guru mengajak anak-anak untuk mewarnai ikan dengan jenis dan ukuran yang berbeda, kemudian anak menempel gambar ikan pada sebuah kertas gambar dengan urutan yang berbeda. Pertemuan yang ketiga guru mengajak anak-anak mengukur panjang pendek sedotan, kemudian menempel pada kertas gambar sedotan yang sesuai dengan ukuran sedotan .Tahap ke tiga adalah tahap observasi, observasi dilakukan disaat tindakan berlangsung, peneliti melakukan observasi dengan instrumen yang sudah disiapkan Pada tindakan siklus I ini diperoleh data sebanyak 11 anak (75\%) dengan kreteria berkembang sesuai harapan dan ada 4 anak $(25 \%)$ dengan kreteria berkembang sangat baik(BSB). Dijelaskan pada diagram pie di bawah ini:

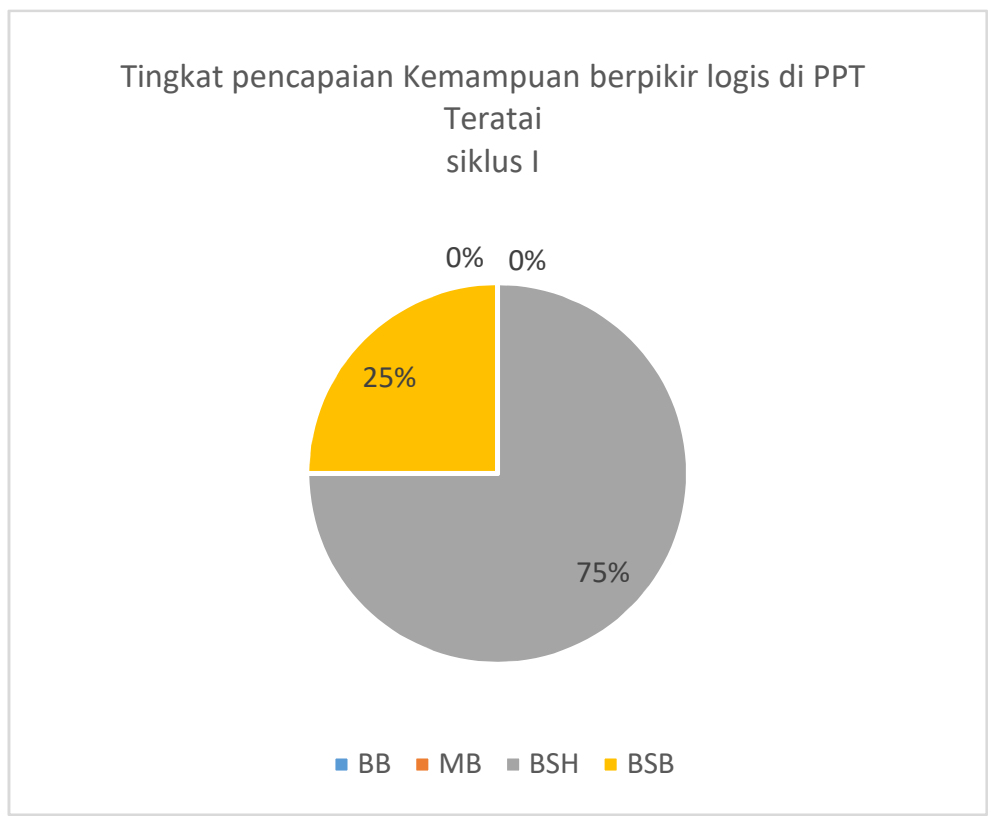

Hasil ini tidak mencapai indikator pencapaian penelitian. Indikator.pencapaian adalah sebanyak $75 \%$ anak memiliki kemampuan berpikir logis dengan kreteria berkembang sangat baik(BSB). Hal ini dikarenakan metode penemuan terbimbing masih baru diterapkan pada pembelajaran di PPT Teratai. Berdasarkan permasalahan diatas penelitian dilanjutkan pada tindakan siklus II dengan 3 kali pertemuan dengan tahapan yang sama pada tindakan siklus I . Tahap pertama adalah perencanaan hal yang dilakukan oleh peneliti masih sama dengan tindakan pada siklus I. Tahap yang kedua adalah pelaksanaan, dalam kegiatan pelaksanan ini peneliti mengajak anak-anak untuk mewarnai bunga matahari dan menempel bagian-bagian dari bunga matahari, anak- 
anak melakukan, mengamati, menempel bagian-bagian bunga .mengelompokkan bunga matahari yang besar dan kecil. Pada pertemuan kedua peneliti mengajak anak-anak untuk mengamati tali- tali yang dimiliki oleh guru, guru meminta anak-anak unruk mengukur tali dan menggolongkan tali yang panjang dan tali yang pendek.Pada pertemuan ke tiga peneliti mengajak anak-anak menempel biji-bijian dengan mengurutkan biji besar dan biji kecil menemukan bagian yang hilang dari kelompok. Tahap selanjutnya adalah tahap observasi yang dilaksanakan pada waktu berlangsungnya kegiatan. Data yang diperoleh dari observasi tindakan siklus II mengalami peningkatan kemampuan sebesar 55\% . Pada siklus II ini diperoleh data sebesar 13 anak(80\%) dengan kreteria berkembang sangat baik(BSB) dan 2 anak (20\%) dengan kreteria berkembang sesuai harapan(BSH). Dijelaskan pada diagram pie dibawah ini:

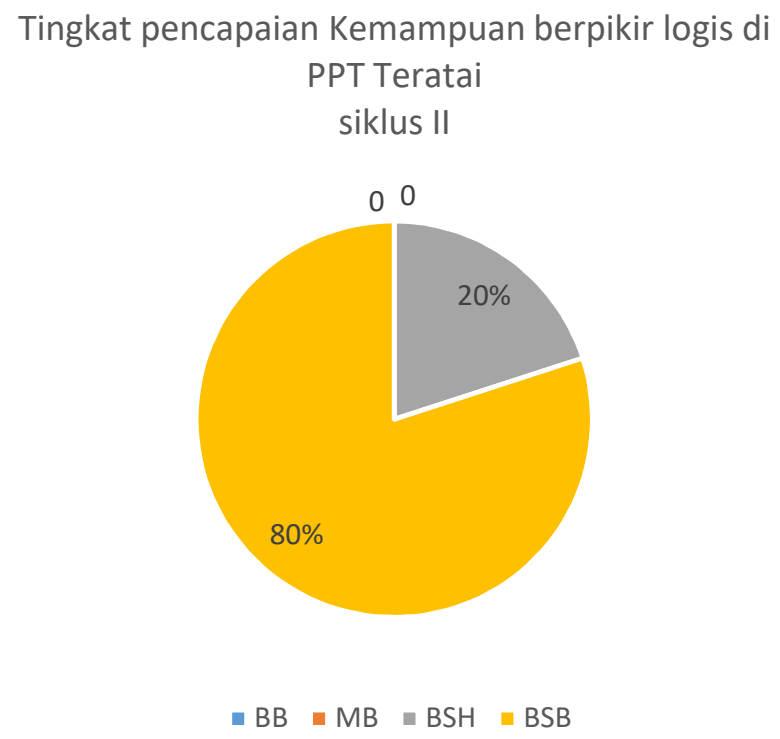

Dengan demikian Penerapan Metode Penemuan Terbimbing dalam meningkatkan berpikir logis anak usia 3-4 tahun di PPT teratai Kenjeran Surabaya sudah mencapai lebih dari indikator pencapaian sebesar $80 \%$ anak mampu berpikir logis. Tahapan ke empat adalah tahap Refleksi dimana data yang diperoleh akan dianalisis dengan metode analisis deskriptif kuantitatif . Tindakan siklus II ini mengalami peningktan kemampuan berpikir logis anak dalam mengetahui ukuran benda yang besar dan kecil, panjang pendek benda, mengelompokan benda berdasarkan jenis atau warnanya, mengetahui bagian benda yang hilang. Kriteria keberhasilan dalam penelitian ini adalah jika persentase kemampuan berpikir logis anak mengalami peningkatan dari siklus I kesiklus II. Apabila terjadi peningkatan dari siklus I ke siklus II maka 
dapat disimpulkan bahwa penerapan metode Penemuan Terbimbing dalam meningkatkan kemampuan berpikir logis anak usia 3-4 tahun di PPT Teratai dapat diterapkan dengan hasil yang baik.

\section{Pembahasan}

Penelitian ini dilaksanakan di PPT Teratai Kenjeran Surabaya. Pelaksanaan penelitian ini dilaksanakan dengan dua siklus tindakan dengan subyek sebanyak 10 anak laki-laki dan 5 anak perempuan.Siklus I dilakukan 3 kali pertemuan dengan kegiatan yang berbeda disetiap pertemuan.

Disetiap pertemuan anak melakukan kegiatan mengamati, memegang, menalar,mengelompokan dll. Siklus I dilaksanakan 3 kali pertemuan dengan waktu 90 menit tiap pertemuan. Tindakan siklus I dilaksanakan dari tanggal $20 \quad-22$ Mei sedangkan siklus II dilaksanakan pada tanggal 27-29 mei 2019. Hasil yang diperoleh dalam tindakan siklus I bahwa 11 anak (75\%)mempunyai kemampuan berpikir logis dengan kreteria berkembang sesuai harapan hal ini belum mencapai indikator pencapaian penelitian sebesar $75 \%$ dengan kreteria berkembang sanggat baik(BSB). Hasil perolehan pada siklus II ada peningkatan kemampuan berpikir logis anak usia 3-4 tahun di PPT Teratai Kenjeran Surabaya..Ada 13 anak(80\%) dengan kreteria berkembang sangat baik, dan ada 2 anak (20\%) dengan kreteria berkembang sesuai harapan(BSH). Adanya peningkatan pada siklus I dan siklus II maka dapat dinyatakan bahwa penelitian tindakan kelas dengan penerapan metode penemuan terbimbing berhasil diterapkan di PPT Teratai dengan pencapaian diatas Indikator sebesar $80 \%$ dengan kreteria berkembang sangat baik(BSB)

\section{PENUTUP}

\section{Kesimpulan}

Berdasarkan hasil penelitian dan pembahasan, dapat diambil kesimpulan bahwa penerapan Metode penemuan terbimbing dalam meningkatkan berpikir logis anak usia 3-4 tahun di PPT Teratai Kenjeran berhasil. Hal ini dapat dibuktikan dengan meningkatnya kemampuan anak-anak dalam berpikir logis mengetahui ukuran besar dan kecil benda, panjang dan pendek benda, mengelompokkan bagian benda berdasarkan warna atau jenisnya, mengetahui bagian benda yang hilang. Kondisi pada tindakan siklus I kondisi kemampuan berpikir logis anak mencapai75\% dengan kreteria berkembang sesuai harapan (BSH) dan 25\% dengan kreteria berkembang sangat baik(BSB), hal ini menunjukan bahwa kemampuan berpikir logis anak masih kurang tidak sesuai dengan 
indikator pencapaian. Kemudian pada tindakan siklus II persentase meningkat menjadi $80 \%$ dengan kreteria berkembang sangat baik(BSB), dan $20 \%$ dengan kreteria berkembang sesuai harapan (BSH) Rata-rata pencapaian dari siklus I dan siklus II kemampuan berpikir logis anak usia 3-4 tahun mengalami peningkatan 55\% dengan kriteria berkembang sangat baik(BSB) dan mengalami penurunan $55 \%$ dengan kriteria berkembang sesuai harapan(BSH).

\section{Saran}

Berdasarkan kesimpulan diatas peneliti memberikan saran agar pelaksanan kegiatan pembelajaran guru lebih kreatif dan menguasai beberapa metode pembelajaran yang akan diterapkan pada pembelajaran dikelas, sehingga peserta didik tidak mengalami kejemuhan dan semua aspek perkembangannya dapat terstimulus dengan baik dan anak lebih semangat untuk belajar sebab pada hakekatnya anak usia dini merupakan individu yang unik,kreatif dan rasa ingin tahu yang tinggi. Guru juga harus kreatif menata ruang kelas agar dapat menunbuhkan semangat belajar anak.

\section{DAFTAR PUSTAKA}

Acep Yoni, dkk. (2010). Menyusun Penelitian indakan Kelas. Yogyakarta: Familia

Arikunto, S. (2010).Prosedur Penelitian Suatu Pendekatan Praktik . Jakarta:Rineka Cipta

Abimanyu,S,dkk. (2010). Strategi Pembelajaran 3 SKS.Direktorat Jendral Pendidikan Tinggi Kementerian pendidikan Nasional. Jakarta

Bektiarso, Singgih(2015),Strategi Pembelajaran,Yogyakarta,LaksBang PRESSindo

Daryanto, (2013). Inovasi Pembelajaran Efektif. Bandung: Yrma Widya

E. Mulyasa. (2009).Praktik Penelitian Tindakan Kelas. Bandung: Rosdakarya.

Eggen, Paul Don Kouchak. 2012. Strategi dan Model Pembelajaran.

Jakarta: PT Indeks

Fadhillah,Muhammad (2014),Desain Pembelajaran PAUD,Jogyakarta, ArRuzz Media

Kurniasih dan Sani (2014, hlm. 64) Sukses Mengimplementasikan Kurikulum 2013. jakarta: Kata Pena

N.M. Muliani1, I. K. Gading2, L.P.P. Mahadewi3(2017)Pengaruh Metode Discovery Terhadap Kemampuan Mengenal Warna Pada Anak Taman Kanak-Kanak, e-Journal Pendidikan Anak Usia Dini Volume 5. No. 1 - Tahun 2017.Singaraja: Universitas Pendidikan Ganesha 
Markaban. (2006). Model Pembelajaran Matematika dengan Pendekatan Penemuan Terbimbing. Yogyakarta: Depdiknas

Peraturan Mentri (Permendiknas)nomor 137 tahun2014 tentang Standar Tingkat Pencapaian Peserta Didik(STPPA)

Retraningrum, W.(2016)Peningkatan Perkembangan Kognitif Anak Usia Dini Melalui Media Bermain Memancing. Vol 3.Nomor 2. Tersedia di https://journal.uny.ac.id/index.php/jppm /article/view/11284 . Diakses pada 7 Februari 2018

Supriadi Oding.( 2013).Perkembangan peserta didik.Yogyakarta, Kurnia Kalam Semesta

Sujiono, Yuliani Nurani. (2009). Konsep Dasar Pendidikan Anak Usia Dini. Jakarta: PT Indeks

Suminah, Enah dkk.(2015).Kerangka Dasar dan Muatan Kurikulum 2013 PAUD.Jakarta.Direktorat Pembinaan PAUD Dirjen PAUD dan Dikmas Kemdikbud.

Suprihatiningrum,Jamil(2017), Strategi Pembelajaran Teori \& Aplikasi, Jogyakarta, Ar-Ruzz Media

Sanjaya, W. 2006. Strategi Pembelajaran. Jakarta: Kencana Prenada Media Group

Senja Nurmala Dewi(2018)Meningkatkan Kemampuan Mengenal Warna Melalui Penggunaan Metode Discovery Pada Anak Usia 4-5 Tahun Di Taman Kanak-Kanak Kartika Fajar Baru Lampung Selatan ,Skripsi, Fakultas Tarbiyah ,Lampung,Universitas Islam Negeri Raden Intan

Undang-Undang Repuplik Indonesia Nomor 20 tahun 2003 tentang Sistem Pendidikan Nasional

Usdiana, D.( 2009). Meningkatkan Kemampuan Berpikir Logis Siswa SMP Melalui Pembelajaran Matematika Realistik. Jurnal Pengajaran MIPA. April 2009. Vol 13, Nomor 1. 1-14. Bandung : Universitas Pendidikan Indonesia

Widiasworo, Erwin. 2017. Strategi dan Metode Mengajar di Luar Kelas(Outdoor Learning). Yogyakarta: Ar-Ruzz Media. 